\title{
Political Connection, CEO Gender, Internal Audit, Corporate Complexity and Audit Fee in Go Public Companies in Indonesia
}

\author{
Alexandros Ngala Solo Wea \\ Economics and Business Departemen, Airlangga University, Indonesia
}

\begin{abstract}
The research is financed by Asian Development Bank. No. 2006-A171(Sponsoring information)
\end{abstract}
Abstract

This study aims to determine the Political Connection, Gender CEO, Internal Audit and Corporate Complexity affect the size of the Audit Fee paid to the Public Accountant by the company. This study uses secondary data in the form of the company's annual report going public in 2015-2017 and using a purposive sampling technique with a total of 247 company data companies. Analysis Techniques Data used in this study are Multiple Linear Regression with Classical Assumption Test. The results of this study indicate that Political Connections (0.003), Internal Audit (0.032) and Corporate Complexity (0.005) have a significant effect on Audit Fee while for Gender CEO variables (0.603) does not affect Audit Fees.

Keywords: Audit Fee, Political Connection, CEO Gender, Internal Audit, Corporate Complexity, Company Risk (DEBT), KAP Type

DOI: $10.7176 / \mathrm{RJFA} / 10-12-02$

Publication date: June $30^{\text {th }} 2019$

\section{Introduction}

The company's financial statement is a description of the condition and performance of the company as it provides information regarding the company's cash flow, management performance and the company's financial position. To improve the quality and reliability of the Financial Report, an audit is carried out by a public accountant to provide a sense of confidence for users of financial statements so that it can be used as a basis for consideration in decision making. Use of Public Accountants in auditing financial statements will increase agency costs, one of which is audit fees. Audit Fee itself is a reward given by the company to the public accountant (independent auditor) for the audit services provided. Basically there are guidelines for payment of audit fees issued by the Indonesian Institute of Certified Public Accountants (IAPI), but in reality, the amount of audit fees paid by companies varies. The amount of the audit fee given to the auditor depends on the risk of the assignment, the complexity of the services provided, the level of expertise needed, the cost structure of the relevant Public Accounting Firm (KAP) and other professional considerations (Mulyadi, 2002).

Political connections often occur in developing countries, one of which is Indonesia. The UNJ Political Observer and Director of the Indonesian Center for Social Political Studies (Puspol), namely Ubedilah Badrun, explained that, "After the reform era, especially since 2004, the political situation in Indonesia began to shift from pragmatic politics to industrial politics (reported from the national.id, on September 07, 2018). It means, in such a situation, the owners of capital have the space to set up and almost completely own political parties and begin to seek their own advantage. This kind of thing often happens in state-owned enterprises (BUMN) in Indonesia.

Political connections do not only occur in BUMN, but also in BUMS. As reported from InvestorDayliIndonesia (September 7, 2018 edition), a family business expert, A.B Susanto, in a discussion on "The Political Attitudes of Family Business in the Realm of Democracy", considered that many family businesses tend to foster close relations with rulers, politicians or political parties with the purpose of getting protection. He considered that the phenomenon of family companies that trigger the growth and maintain the sustainability of their business through close relations with the authorities or political parties has been going on for a long time, either in the center or in the regions or at various scales.

From a research conducted by Ariningrum and Dayanti (2017) and by Primasari and Sudarno (2013), they found that companies that have political connections will pay a higher audit fee than those which do not. Companies that have political connections are risk takers so they are susceptible to business failures that make audit risk higher so that auditors will ask for higher audit fees (Primasari and Sudarno, 2013).

Reported from Tribunnews (April 13, 2017 edition), the percentage of women in Indonesia who are leaders of companies has increased quite high, where in 2016 the percentage of women in Indonesia who occupied the top leadership positions reached $46 \%$. The managerial structure of the company includes gender, size and share ownership. Differences between individuals due to gender and ethnicity tend to influence decision making. Companies with female CEOs have higher guarantee preferences, as well as more timely reliability of financial reporting and audit reporting to maintain their leadership (Harjoto, Laksamana and Lee, 2015). Besides, the research from Huang, Huang, and Lee (2014) stated that the auditor could see that companies with female CEOs had less inherent risks, related to material misstatement of financial statements so that auditors would be willing 
to reduce their scope and have an impact on low audit fee.

The assessment of management performance by the principal tends to encourage the occurrence of deviant behavior from the management itself. One form of deviant behavior carried out by management is the existence of earnings management as happened at PT. Lippo Tbk and PT. Kimia Farma Tbk that detected financial statement manipulation. From the example above, we can see the important role of the effectiveness of corporate governance and internal auditors as a part of monitoring the company. In this case, the role of governance effectiveness and internal control acts as the supervisor of the company's management. Hapsari and Laskito (2013) detailed that in carrying out their duties, external auditors and internal auditors have different goals, responsibilities, qualifications, and tasks in different activities, but both have a common interest that demands coordination for the company's interests. Yasin and Nelson (2012) said that the broad scope of internal audit within the company would make the auditor depend on the work of internal auditors and therefore would reduce the scope of work of the external auditor to suppress audit fees imposed on the company.

In carrying out audit assignments by public accountants, in addition to understanding the scope of the audit and company risks, public accountants also need to understand the complexity of the company's business. The complexity of these transactions can come from transactions of companies that use foreign currencies, the number of subsidiaries, the number of branches of the company, and the existence of business operations of companies abroad. If the auditor finds such condition, the auditor is faced with the complexity of the work. The auditor will certainly have difficulty in determining the reasonableness of the presentation of the Company's Financial Statements. To be able to overcome this problem, automatically auditors need long time and process which then will affect the size of the audit fee (Ariningrum, 2013).

The talks about Audit Fee is a dilemmatic case, because auditors are required to have an objective attitude and high independence in conducting audit assignments. But on the other hand, a public accountant must get Fee. The topic of Fee audits is interesting to study given the increasing competition between public accountants and the auditors competing in offering audit services with varying prices. Another reason is the determination of the amount of audit fees that are subjective, meaning that the amount of audit fees offered depends on the quality of the bargaining between the client and the auditor. In addition, the topic of audit fees is becoming increasingly attractive considering the policy of determining audit fees by the Public Accountant Firm is one aspect of the quality review against the Public Accounting Firm. Based on the background explanation above, the formulation of the problem in this paper is: do political connections, CEO Gender, Internal Audit and Corporate Complexity affect the Audit Fee?

\section{Literature Review}

\subsection{Theory of Agency}

Theory of agency developed by Jensen and Meckling (1976) described the agency relationship between the principal and the agent as a relationship arising from the existence of a contract agreed upon between the two parties to carry out the tasks that are in the principal's interest. Due to conflict of interest between the principal and the agent, an independent party is required, namely an independent auditor who will carry out monitoring procedures with their agent. The monitoring procedure will increase agency costs, and one form of agency costs is the costs incurred to perform audit procedures by third parties, which is in the form of audit fees (Jensen and Meckling, 1976).

\subsection{Concept and Theory of Gender}

Gender is a characteristic that distinguishes men and women that can be seen in terms of social, cultural, values, behavior, mentality, emotions and other non-biological factors. Gender places more emphasis on differences in the nature of one's masculinity and femininity. Sundari Sasongko (2009:7) stated that gender is a difference in roles, functions, and responsibilities between men and women which are the results of social construction and can change along the times. Nurture theory developed by Edward Wilson from Harvard University (1975) divides the struggle of women sociologically into two major groups, namely the concept of nurture (cultural construction) and the concept of nature (natural). According to the nurture theory, the difference between women and men is essentially the result of socio-cultural construction so that it produces different roles and tasks.

\subsection{Development of Hypotheses}

\subsubsection{Effect of Political Connections on Audit Fee}

The perspective on agency relations in the theory of agency is the basis used to understand political connections in this study. The auditor will see that companies with board of commissioners and board of directors getting associated with political connections have a higher inherent risk; because political connections or political closeness within the company can increase fraudulent practices carried out by the company (Gul, 2006). Jhonsol and Milton (2003) in Gul (2006) also said that companies that have political connections are at risk of experiencing greater failure. In addition, the audit becomes more risky so that audit fees are also likely to 
increase. Therefore, the hypothesis formulated is as follows:

H1 : The company's political connection has a significant effect on Audit Fee.

\subsubsection{Effect of CEO's Gender on Audit Fee}

The concepts and theories of gender emphasize that gender is the difference in roles, functions, and responsibilities between men and women which are the result of social construction and can change according to the times (Sundari Sasongko,2009: 7). The existence of a woman being appointed as a member of a board in a company is based on the reason that women can be a signal whether the company's performance is going well, instead of being the sign that in the future women can make grant a good impact to the company (Nurfadilla (2016) in Aluy, Tulung and Tasik (2017). In addition, Huang, Huang and Lee (2014) developed the idea that female CEOs prefer to reject risk compared to men, so that auditors can see that female CEOs have less inherent risk of financial misstatement, which then reduces the auditor's scope and resulting in low audit fees. Therefore the hypothesis formulated is as follows:

H2 : The company CEO's Gender has a significant effect on Audit Fee.

\subsubsection{Effects of Internal Audit on Audit Fee}

Internal audit contained in the company is an inseparable part of corporate governance practices so that it is inseparable from Theory of Agency. The supervision effort carried out by the principal creates agency costs. The existence of an internal audit function in a company can actually assist external auditors in carrying out audit assignments requested by the company. Hapsari and Laksito (2013) said that in carrying out their duties, external auditors and internal auditors have different goals, responsibilities, qualifications, and tasks in different activities, but both have a common interest that demands coordination for the interests of the company. Internal auditors in the company are expected to have a high level of professionalism so that it can reduce the level of errors in the presentation of financial statements due to the fact that it can reduce the scope of the external auditor. The reduced scope of work, invoices and procedures of external auditors will affect the amount of audit fee requested by the external auditors. Referring to this, the third hypothesis proposed in this study is:

H3 : Internal Audit has a significant effect on the External Auditor Fee.

\subsubsection{Effect of Corporate Complexity on Audit Fee}

Theory of agency describes the relationship of security between the principal and the agent that can lead to conflict between the two parties. The business complexty according to Cameran (2005) in Ardianingsih (2013) is related to the complexity of transactions in the company. When the auditor finds that a company carries out related party transaction activities, the auditor will be faced with the complexity of the work. The auditor will find it difficult to determine the reasonableness of the presentation of financial statements. To be able to decide, the auditor requires a fairly long process which then triggers higher fee terms. Referring to this, the hypothesis proposed in this study are:

\section{H4 : Corporate Complexity has a significant effect on External Auditor Fee.}

\section{Research Method}

Testing the hypothesis in this study used Multiple Regression analysis. The regression equation in this study is as follows :

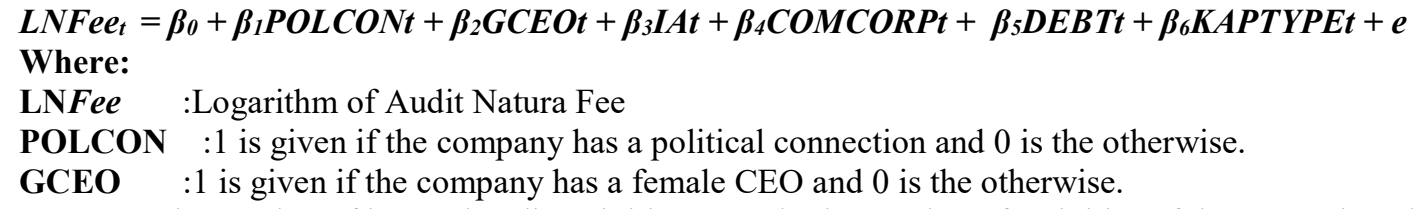

\subsection{Definition of Operational Variables}

\subsubsection{Dependent Variable}

Dependent variable in this study was the Audit Fee. Audit fee is the amount that must be spent by each company to finance the services of external auditors who have conducted audits of the financial statements of the company concerned. Fee audit variable in this study was measured using Natural Logarithms of the amount of Audit Fee (Ariningrum dan Diyanty, 2017).

\subsubsection{Independent Variables}

\section{Political Connection}

The company is considered to have political connections if at least one of the major shareholders (one who 
controls at least $10 \%$ of the total shares with voting rights) or one of the company leaders (CEO, president director, vice president director, chairman or secretary) is a member of parliament, minister or person who is closely related to the top politician or political party (Faccio, 2006). In this study the company is said to have a political connection if the company fulfills one of the following criteria according to Fan, Wong and Zhang (2007) and Habib, Muhammadi, and Jiang (2017)

1. One of the shareholders with a minimum of $10 \%$ is a minister or former minister, member of parliament, former or member of the military.

2. At least one of the board of directors has dual positions as a politician affiliated with a political party, as a government official, as a military official, a former government official or a former military official

3. At least one of the board of commissioners has dual positions as a politician affiliated with a political party, as a government official, as a military official, a former government official or a former military official

4. Companies that explain the profile of the board of commissioners and their directors are former or current regional heads, former/ members of politicians, former/ members of military, former/ member of ministers during the research period.

\section{CEO Gender}

Gender is a concept used to identify differences in men and women in terms of socio-cultural, values, mentality and other non-biological factors and also emphasizes the differences in masculinity and femininity of a person (Kusumawati, 2007).

\section{Internal Audit}

Agoes (2004: 221) defined internal audit as an examination conducted by the company's internal audit section, both on financial statements and notes on financial statements, as well as adherence to policies from predetermined top management, and adherence to government regulations and professional ties that apply. The more activities carried out by internal audits show that the number of objects audited by the Internal Audit Unit in the company in one period, which indicates the extent or small scope of the internal audit.

\section{Corporate Complexity}

Corporate Complexity according to Cameran (2005) in Ardianingsih (2013) is related to the complexity of transactions in the company. The complexity of these transactions can come from transactions of companies that use foreign currencies, the number of subsidiaries, the number of branches of the company and also the business operations of companies abroad. The auditor will find it difficult to determine the reasonableness of the presentation of financial statements. To decide, the auditor requires a fairly long process that triggers higher fee terms.

\subsubsection{Control Variable}

\section{Company Risk (DEBT)}

Risk for company organizations generally comes from the element of uncertainty that causes depressed profitability or even cause losses. Public Accounting Firms can make company's risk a matter of consideration to determine their audit service rates. Company risk is considered as one of the important factors that can determine the amount of audit fees paid by the company in whcih higher risk of the company will lead to higher audit fee (Naser and Nuseibeh, 2008).

\section{Types of Public Accounting Firms (KAP)}

The type of Public Accountant Office in this study can be divided into two groups, which are: KAP affiliated with the Big Four KAP and KAP not affiliated with the Big Four KAP. Companies tend to choose KAP based on reputation criteria and on guarantees for the credibility of financial statements. Public accounting firms included in the Big Four are expected to produce high-quality financial statements and are expected to make a few errors so that they have a higher audit fee than non-Big Four KAP. (Yulio, 2016).

\subsection{Population and Sample}

The selection process samples in this study will be presented in the following table:

Table 1. Sample Selection Process

\begin{tabular}{|l|c|c|c|c|}
\hline \multicolumn{1}{|c|}{ Sample Criteria } & $\mathbf{2 0 1 5}$ & $\mathbf{2 0 1 6}$ & $\mathbf{2 0 1 7}$ & TOTAL \\
\hline Companies go public listed on the IDX (2015-2017) & 514 & 528 & 564 & 1606 \\
\hline Companies that do not publish the Annual Report & $(30)$ & $(39)$ & $(60)$ & $(129)$ \\
\hline & $\mathbf{4 8 4}$ & $\mathbf{4 8 9}$ & $\mathbf{5 0 4}$ & $\mathbf{1 4 7 7}$ \\
\hline Companies that do not disclose audit fees in the Annual Report & $(270)$ & $(246)$ & $(251)$ & $(767)$ \\
\hline Companies that do not disclose the amount of Internal Audit activities & $(135)$ & $(162)$ & $(166)$ & $(462)$ \\
\hline Companies that meet criteria & $\mathbf{7 9}$ & $\mathbf{8 1}$ & $\mathbf{8 7}$ & $\mathbf{2 4 7}$ \\
\hline
\end{tabular}

\section{RESULT AND DISCUSSION}

This study used all go public companies listed on the Indonesia Stock Exchange (IDX) in 2015-2017. The 
selection of go public companies as the subject of research is intended so that all information needed by researchers can be reached.

\subsection{Frequency Analysis}

\subsubsection{Political Connection Variable}

Descriptive statistics for political connection variable are presented in the following table:

Table 2. Descriptive Statistics-Political Connections

\begin{tabular}{|l|c|c|}
\hline \multicolumn{1}{|c|}{ Category } & Frequency & Percentage \\
\hline Companies with political connections & 154 & 62.3 \\
\hline Companies that have no political connections & 93 & 37.7 \\
\hline TOTAL & $\mathbf{2 4 7}$ & $\mathbf{1 0 0}$ \\
\hline
\end{tabular}

Source: data processed

Table 2 shows descriptive statistics for political connection variables in which 154 sample companies $(62.3 \%)$ were politically connected while 93 companies did not have political connections $(37.7 \%)$.

\subsubsection{CEO Gender Variable}

Descriptive statistics for CEO Gender variable are presented in the following table:

Table 3. Descriptive Statistics-Gender CEO

\begin{tabular}{|l|c|c|}
\hline \multicolumn{1}{|c|}{ Category } & Frequency & Percentage \\
\hline Companies with CEOs Women & 19 & 7.7 \\
\hline Companies with CEOs Man & 228 & 92.3 \\
\hline TOTAL & $\mathbf{2 4 7}$ & $\mathbf{1 0 0}$ \\
\hline
\end{tabular}

Source: data processed

Table 3 shows descriptive statistics for CEO Gender variable, in which 19 sample companies $(7.7 \%)$ were led by female CEOs, while most companies were led by male CEOs, namely 229 companies $(92.3 \%)$

\subsubsection{Type of KAP Variable}

Descriptive statistics for Type of KAP variable are presented in the following table:

\section{Table 4 Descriptive Statistics-KAP Type}

\begin{tabular}{|l|c|c|}
\hline \multicolumn{1}{|c|}{ Category } & Frequency & Percentage \\
\hline Public Accounting Firm affiliated with the Big Four & 163 & 66 \\
\hline Public Accounting Firm not affiliated with the Big Four & 85 & 34 \\
\hline TOTAL & $\mathbf{2 4 7}$ & $\mathbf{1 0 0}$ \\
\hline
\end{tabular}

Source: data processed

Table 4 shows descriptive statistics for Type of KAP variable, where 163 sample companies $(66 \%)$ used Big Four affiliated KAPs in conducting audits, while 85 sample companies (34\%) use KAPs that are not affiliated with the Big Four.

\subsection{Descriptive Statistics}

Table 5 below presents the results of descriptive statistics for the Audit Fee, Internal Audit, Business Complexity and Corporate Risk Variable (Debt To Equity Ratio), which is as follows:

Table 5. Descriptive Statistics

\begin{tabular}{|l|c|c|c|c|c|}
\hline \multicolumn{1}{|c|}{ Variabel } & N & Min & Max & Mean & Std. Deviation \\
\hline Fee Audit & 247 & 18,84 & 24,50 & 21,0220 & 1,11009 \\
\hline Internal Audit & 247 & 2 & 57.589 & 613,80 & 5178,236 \\
\hline Corporate Complexity & 247 & 0 & 70 & 6,88 & 9,491 \\
\hline Corporate Risk & 247 & $-2,17$ & 18,21 & 2,8497 & 3,00196 \\
\hline
\end{tabular}

Source: data processed

\subsubsection{Fee Audit Variable}

Table 5 shows that the audit fee variable had a minimum value of 18.84 owned by PT. Nusa Raya Cipta Tbk (NRCA) in 2017, in which the company paid an audit fee of Rp152,000,000.00 while the maximum value of the audit fee variable was 24.50 owned by PT. Telekomunikasi Indonesia Tbk (TLKM) in 2017 in which the company paid an audit fee of Rp43,700,000,000.00. The mean value for the audit fee variable was 21.0220 indicating that out of a total of 247 company samples, there were 116 companies that paid for audit fees above the mean value.

\subsubsection{Internal Audit Variable}

Table 5 shows that the internal audit variable had a minimum value of 2 owned by PT. Dua Putra Utama Makmur Tbk (DPUM) in 2015. This may occur because the Internal Audit Unit was only managed by 1 (one) person, as disclosed in the statement, where the Internal Audit Division conducted checks related to the recording process of building maintenance costs and checks related to Petty Cash. The maximum value of the 
internal audit variable was 57,589 owned by PT. Bank Rakyat Indonesia Tbk (BBRI) in 2017. The mean value for the internal audit variable was 613.80 indicating that out of a total of 247 sample companies, 6 sample companies had a number of internal audit activities in one period above the mean value.

\subsubsection{Business Complexity Variable}

Table 5 shows that for Business Complexity variable, there were 64 samples of companies that did not have subsidiaries during the study period (2015-2017) with a minimum value of 0, such as PT. Adira Dinamika Multi Finance Tbk (ADMF), PT. Bank Rakyat Indonesia Agroniaga Tbk (AGRO) and also PT Excel Axiata Tbk (EXCL). The maximum value of the Business Complexity variable was 70 owned by PT. Global Medicom Tbk (BMTR) in 2015. The mean value for business complexity variable was 6.88 indicating that out of a total of 247 company samples, 89 companies had a number of subsidiaries above the mean value. The standard deviation for business complexity variable in this study was 9,491

\subsubsection{Company Risk Variable (Debt Equity Ratio)}

Table 5 shows that the Debt Equity Ratio variable had a minimum value of -2.17 owned by PT Bumi Resource Tbk (BUMI) in 2015. This was because in 2015, PT. Bumi Resource Tbk had a capital deficit of Rp40,073,257,329,145. The maximum value of the Debt Equity Ratio variable was equal to 18.21 owned by PT. Bank Pundi Tbk (BEKS) in 2015. This showed that in 2015, PT. Bank Pundi Tbk underwent financial distress due to considerably large amount of debt. The mean value for the Debt Equity Ratio variable was 2.8497 indicating that out of a total of 247 company samples, 92 sample companies had a Debt Equity Ratio above the mean value. In addition, it can be said that out of 247 company samples, 157 companies experienced financial distress owing to the fact that the value of the Debt Equity Ratio was greater than $1(\geq 1)$ including sample companies that experienced a capital deficit.

Table 6. Hypothesis Test

\begin{tabular}{|l|c|r|c|}
\hline \multirow{2}{*}{ Model } & Unstandardized Coefficients & \multirow{2}{*}{ B } & \multirow{2}{*}{ Sig } \\
\cline { 2 - 3 } & 19,859 & 152,537 &, 000 \\
\hline (Constant) &, 366 & 3,014 & $\mathbf{, 0 0 3}$ \\
\hline Koneksi Politik &, 114 &, 521 &, 603 \\
\hline Gender CEO & $2,400 \mathrm{E}-5$ & 2,162 & $\mathbf{, 0 3 2}$ \\
\hline Internal Audit &, 018 & 2,830 & $\mathbf{, 0 0 5}$ \\
\hline Kompleksitas Usaha &,- 003 &,- 139 &, 890 \\
\hline Risiko Perusahaan (DER) & 1,221 & 9,719 & $\mathbf{, 0 0 0}$ \\
\hline Jenis KAP & &
\end{tabular}

Source: data processed

The results of multiple linear regression testing produced a regression model, which is as follows:

LNFee $=19,859+0.366$ POLCON + 0.114GCEO + 2,4005AIA + 0.018CORCOMP - 0.003DER + $1,221 \mathbf{K A P T Y P E}+\boldsymbol{e}$

The statistical test results for political connection variable presented in Table 6 showed a significance value of 0.003 (smaller than 5\%) which indicates that H1 was accepted; it means Political Connections had a significant effect on audit fees paid by companies. This signifies that politically connected companies pay higher audit fees compared to companies that are not politically connected. Companies that have political connections have a high risk of failure and higher audit risk which triggers a higher audit fee. This result is also supported by research conducted by Primasari and Sudarno (2013) and the one conducted by Ariningrum and Diyanty (2017).

The statistical test results for the CEO Gender variable presented in Table 6 had a significant value of $\mathbf{0 . 6 0 3}$ (greater than 5\%) indicating that $\mathbf{H 2}$ was rejected; it means the CEO Gender variable did not affect audit fees. The presence of women in the ranks of the board of directors as company leaders in Indonesia can be said to be very minimal, which is around $6 \%$ in the board of directors (cited from www.worldbank.org). This result was also supported by the findings of researchers that out of a total of 247 company samples, only 19 company samples $(7.7 \%)$ were led by female CEOs, while the remaining 228 company samples $(93.3 \%)$ were led by Male CEOs. This is probably what causes the auditor not to pay too much attention to the inherent risk of the female CEO, so it did not affect the amount of the audit fee if the company was led by the female CEO.

The statistical test results for the internal audit variables presented in Table 6 had a significance value of 0.032 (less than 5\%) indicating that $\mathbf{H 3}$ was accepted; it means Internal Audit had a significant effect on audit fee. These results indicate that the presence of Internal Audit in the company is considered as complementary, which is completing the external audit function. This is due to the fact that the internal audit function is considered as one of the elements of the external auditor's control process. This increase in demand for external audits will ultimately also increase external auditor fees. This result is in line with the research conducted by Goodwin-Stewart and Kent (2006) and the one conducted by Hay, Knechel, and Ling (2008).

Statistical test results for Business complexity variable presented in Table 6 had a significance value of 0.005 (less than 5\%) meaning that $\mathbf{H} 4$ was accepted, so it can be said that Business Complexity had a significant 
effect on audit fees. This result is in line with the research conducted by Naser and Nuseibeh (2008) indicating that Business Complexity affected audit fees. This shows that the number of subsidiaries that lead to higher business complexity in the company so that the audit risk gets higher and the audit process gets more complicated, triggers an increase in audit fees.

\subsection{Additional Analysis}

In addition, the results of statistical tests for the two control variables, which were Company Risk and types of KAP presented in Table 6, showed significant values of 0.890 (greater than 5\%) and 0.00 (smaller than 5\%). The results of these statistical tests indicated that Company Risk did not affect audit fees. In general, companies need a source of capital where the capital can be obtained from loans from outside parties. The high level of company debt reflects the company's large risk because of the possibility that the company cannot pay its debt. It is possible that the Debt Equity Ratio in this measurement did not represent the actual risk.

The results of the statistical test for the Type of KAP control variable showed that the Type of KAP variable affected audit fees. Companies tend to choose KAP based on reputation criteria and on guarantees for the credibility of financial statements. The public accounting firm included in the Big Four is expected to produce high-quality financial statement and is expected to make a few errors in order to have a higher audit fee. This result is in line with the research conducted by Hapsari and Laksito (2013) and the one conducted by Chandra (2016).

\section{CONCLUSION}

Based on the results of hypothesis testing in multiple linear regression analysis, it was found that the CEO Gender variable did not affect the Audit Fee paid by the company to the auditor, while the Political Connection, Internal Audit and Business Complexity variable affected the Audit Fee paid by the company to the Auditor. Practically, the results of this study provide information related to the competitive market of audit services in Indonesia and their impact on audit fees. This information can be a consideration for regulators who are authorized to ensure that this intense competition does not cause unnatural and too low audit fees that have the potential to reduce audit quality. In addition, the existence of female CEOs and male CEOs as company leaders does not affect the amount of the audit fees paid because men and women can produce quality jobs regardless of gender status, so that gender is not a barrier to achieving good audit quality that has an impact on fees audit. The limitation of this study is the disclosure of audit fees and the number of internal audit activities in the Company's Annual Report that are still voluntary, causing many companies that do not meet the sample criteria which then affects the number of research samples used that is relatively small, so the next researcher is expected to be able to add the number of samples of the company by combining the use of secondary data and primary data, to obtain more complete data on Audit Fee and Internal Audit Unit in companies in Indonesia.

\section{References}

Adhikari, A., Derashid, C., \& Zhang, H. (2006). Public Policy, Political Connections, and Effective Tax Rates: Longitudinal evidence from Malaysia. Journal of Accounting and Public Policy, 25 (5), 574-595.

Agoes, S. (2004). Auditing (Pemeriksaan Akuntan) Oleh Kantor Akuntan Publik (Edisi Tiga ed.). Jakarta: Fakultas Ekonomi Universitas Trisakti.

Alvin A, A., Elder, R. J., \& Beasley, M. S. (2012). Auditing and Assurance Services an Integrated Approach (14th ed.). New Jersey: Prentice-Hall.

Anshori, M., \& Iswati, S. (2009). Metodologi Penelitian Kuantitatif. Surabaya: Airlangga University Press.

Ardianingsih, A. (2013). Hubungan Komite Audit dan Kompleksitas Usaha dengan Audit Fee. Jurnal Ekonomi Dan Bisnis, 13 (2),20-28.

Ariningrum, I., \& Diyanty, V. (2017). The Impact of Political Connections and the Effectiveness of Board of Commissioner and Audit Committees on Audit Fees. Australasian Accounting, Business and Finance Journal, 11 (4), 53-70.

Aswadi Abdul Wahab, E., Mat Zain, M., \& James, K. (2011). Political connections, corporate governance and audit fees in Malaysia. Managerial Auditing Journal, 26 (5), 393-418.

Badrun, Ubedilah.(2018). Politik di Indonesia.[Online] Available: http://www.nasional.kontan.id/. September 07, 2018

Boynton, W. C., Johnson, R. N., \& Kell, W. G. (2003). Modern Auditing. In (Edisi Tujuh ed.). Jakarta: Erlangga.

Chandra, M. O. (2016). Pengaruh good corporate governance, karakteristik perusahaan dan ukuran Kap terhadap fee audit eksternal. Jurnal Akuntansi Bisnis, 13 (26), 174-194.

Caneghem, T. V. (2010). Audit pricing and the Big4 fee premium: evidence from Belgium. Managerial Auditing Journal, 25 (2), 122-139.

Chen, Y., Eshleman, J. D., \& Soileau, J. S. (2016). Board Gender Diversity And Internal Control Weaknesses. Advances in Accounting, 33, 11-19. 
Claudia Aprilinda, A., Joy Elly, T., \& Hizkia HD, T. (2017). Pengaruh Keberadaan Wanita Dalam Manajemen Puncak Dan Kepemilikan Manajerial Terhadap Kinerja Keuangan Perbankan (Studi Pada Bank Bumn Dan Bank Swasta Nasional Devisa Di Indonesia). Jurnal EMBA: Jurnal Riset Ekonomi, Manajemen, Bisnis dan Akuntansi, Volume 5 (2), 821-828.

D’yan, M. V. J. P., \& Yaniartha, S. (2013). Pengaruh Tekanan Anggaran Waktu, Kompleksitas Tugas Dan Reputasi Auditor Terhadap Fee Audit Pada Kantor Akuntan Publik (Kap) Di Bali. E-Jurnal Akuntansi, ISSN:2302-8556, 132-146.

El-Gammal, W. (2012). Determinants of audit fees: Evidence from Lebanon. International Business Research, $5(11), 136$.

Faccio, M. (2006). Politically connected firms. American economic review, 96 (1), 369-386.

Faccio, M., Marchica, M.-T., \& Mura, R. (2016). CEO gender, corporate risk-taking, and the efficiency of capital allocation. Journal of Corporate Finance, 39, 193-209.

Fan, J. P., Wong, T. J., \& Zhang, T. (2007). Politically connected CEOs, Corporate Governance, and Post-IPO performance of China's newly partially privatized firms. Journal of Financial Economics, 84 (2), 330-357.

Fisman, R. (2001). Estimating the value of political connections. American economic review, 91(4), $1095-1102$.

Ghosh, A. A., \& Tang, C. Y. (2015). Assessing financial reporting quality of family firms: The auditors' perspective. Journal of Accounting and Economics, 60 (1), 95-116.

Ghozali, I. (2006). Analisis Multivariat Dengan Program SSPS (Edisi Empat ed.). Semarang: Badang Penerbit Universitas Diponegoro.

Goodwin-Stewart, J., \& Kent, P. (2006). The Use Of Internal Audit By Australian Companies. Managerial Auditing Journal, 21 (1), 81-101.

Goodwin-Stewart, J., \& Kent, P. (2006). Relation between external audit fees, audit committee characteristics and internal audit. Accounting \& Finance, 46 (3), 387-404.

Gul, F. A. (2006). Auditors' Response to Political Connections and Cronyism in Malaysia. Journal of Accounting Research, 44(5), 931-963.

Habib, A., Muhammadi, A. H., \& Jiang, H. (2017). Political connections and related party transactions: evidence from Indonesia. The International Journal of Accounting, 52 (1), 45-63.

Hapsari, E. D., \& Laksito, H. (2013). Pengaruh Fungsi Audit Internal Terhadap Fee Auditor Eksternal. Diponegoro Journal of Accounting, 2 (2), 748-757.

Harjoto, M. A., Laksmana, I., \& Lee, R. (2015). The impact of demographic characteristics of CEOs and directors on audit fees and audit delay. Managerial Auditing Journal, 30 (8/9), 963-997.

Hay, D., Knechel, W. R., dan Ling, H. (2008). Evidence On The Impact Of Internal Control And Corporate Governance On Audit Fees. International Journal of Auditing, 12 (1), 9-24.

Huang, T.-C., Huang, H.-W., \& Lee, C.-C. (2014). Corporate Executive's Gender And Audit Fees. Managerial Auditing Journal, 29 (6), 527-547.

Immanuel, R., \& Yuyetta, E. N. A. (2014). Analisis Faktor-Faktor Yang Mempengaruhi Penetapan Audit Fees (Studi Empirik Pada Perusahaan Manufaktur di BEI). Diponegoro Journal of Accounting, 3 (3),1-12.

Indriantoro, N., \& Supomo, B. (2002). Metodologi Penelitian Bisnis Untuk Akuntansi dan Manajemen (EdisI Dua ed.). Yogyakarta: BPFE.

Jensen, M. C., \& Meckling, W. H. (1976). Theory of the Firm : Managerial behavior, agency costs and ownership structure. Journal of Financial Economics, Volume 3 (4), 305-360.

Kusumawati, A. (2007). Kepemimpinan dalam Perspektif Gender: Adakah Perbedaan?. Profit (Jurnal Administrasi Bisnis), 1 (1),33-36.

Lakhal, F., Aguir, A., Lakhal, N., \& Malek, A. (2015). Do women on boards and in top management reduce earnings management? Evidence in France. Journal of Applied Business Research, 31 (3), 1107.

Leuz, C., \& Oberholzer-Gee, F. (2006). Political relationships, global financing, and corporate transparency: Evidence from Indonesia. Journal of Financial Economics, 81 (2), 411-439.

Mulyadi. (2002). Auditing (Edisi Enam ed.). Jakarta: Salemba Empat.

Moh Nazir. (2003). Metode Penelitian. Jakarta: Ghalia Indonesia

Naser, K., \& Nuseibeh, R. (2008). Determinants Of Audit Fees: Empirical Evidence From An Emerging Economy. International Journal of Commerce and Management, 17 (3), 239-254.

Peni, E., \& Vähämaa, S. (2010). Female executives and earnings management. Managerial Finance, 36 (7), 629 645.

Primasari, R., \& Sudarno, S. (2013). Pengaruh Koneksi Politik Dan Corporate Governance Terhadap Fee Audit. Diponegoro Journal of Accounting, 2 (2), 344-359.

Putri, B. W. (2012). Penentuan Kualitas Audit Berdasarkan Ukuran Kantor Akuntan Publik dan Biaya Audit. Jurnal Ilmiah Mahasiswa Akuntansi, 1 (4), 60-64.

Salsabila, A., \& Prayudiawan, H. (2011). Pengaruh Akuntabilitas, Pengetahuan Audit dan Gender Terhadap Kualitas Hasil Kerja Auditor Internal (Studi Empiris Pada Inspektorat Wilayah Provinsi DKI Jakarta). 
Jurnal Telaah dan Riset Akuntansi, 4 (2), 155-175.

Singh, H., \& Newby, R. (2010). Internal Audit and Audit Fees: further evidence. Managerial Auditing Journal, 25 (4), 309-327.

Sugiyono. (2013). Metode Penelitian Kuantitatif, Kualitatif dan R \& D. Bandung: Alfabeta.

Suharli, M., \& Nurlaelah, N. (2008). Konsentrasi Auditor dan Penetapan Fee Audit: Investigasi Pada BUMN. Jurnal Akuntansi dan Auditing Indonesia, 12 (2), 133-148.

Sundari Sasongko, Sri. (2009). Konsep dan Teori Gender. Jakarta : BKKBN.

Supomo, N. I. d. B. (2002). Metodelogi Penelitian Bisnis Untuk Akuntansi dan Manajemen (Edisi Dua ed.). Yogyakarta.

Susanto, A.B.(2018). Sikap Politik Perusahaan Keluarga di Indonesia. [Online] Available: http://www.mediaindonesia.com/. September 07,2018.

Tuanakotta, T. M. (2013). Audit Berbasis ISA (International Standards on Auditing) Jakarta: Salemba Empat.

Wenfeng, W., Wu, C., \& Rui, O. M. (2012). Ownership and the value of political connections: Evidence from China. European Financial Management, Volume 18 (4), 695-729.

Wibowo, R., \& Rohman, A. (2013). Pengaruh Governance Structure dan Fungsi Internal Control terhadap Fee Audit Eksternal pada Perusahaan Publik di Indonesia. Diponegoro Journal of Accounting, 2 (2),1-13.

Wicaksono, A. P. N. (2017). Koneksi Politik dan Aggresivitas Pajak: Fenomena di Indonesia. Akuntabilitas:Jurnal Ilmu Akuntansi, 10 (1), 167-180.

Widhiarso, Wahyu. (2011). Analisis Data Penelitian Dengan Variabel Kontrol, Tersedia dari: URL: http://widhiarso.staff.ugm.ac.id/files/Analisis Data dengan Menggunakan Variabel Kontrol.pdf diakses 6 September 2018.

Wulandari, L. (2018). Pengaruh Political Connection Pada Dewan Komisaris Dan Dewan Direksi Terhadap Kinerja Perusahaan Sektor Pertambangan Yang Terdaftar Di Bursa Efek Indonesia (BEI) Periode Tahun 2010-2014. CALYPTRA, 7 (1), 1196-1296.

Yasin, F. M., \& Nelson, S. P. (2012). Audit Committee and Internal Audit: Implications on Audit Quality. International Journal of Economics, Management and Accounting, 20 (2), 187.

Yulio, W. S. (2016). Pengaruh Konvergensi IFRS, Komite Audit, Dan Kompleksitas Perusahaan Terhadap Fee Audit. Jurnal Akuntansi Bisnis, 15 (29), 77-92. 